\title{
DUTGH TRADE WITH THE PEOPLE'S REPUBLIC OF CHINA
}

\author{
C. E. KROESE*
}

INTRODUCTION

The People's Republic of China is potentially a vast market for foreign goods and services and a potent source of exports for the world community. The recent thaw in Sino-American relations, among other factors, has caused a growing awareness of this potential. At the same time, growing Chinese economic strength and stability-coupled with the present Chinese domestic and world political situation-have caused China to deal increasingly in Western markets.

The Netherlands' long history of trade with China is a source of past experience for other Western countries now considering expansion of commercial contacts with the People's Republic. This article describes the development of Sino-Dutch trade and analyzes the current status of Chinese trade as manifested in the Dutch experience. Finally, the basic procedures involved in trading with the People's Republic are discussed.

I

\section{The Development of Sino-Dutch Trade}

Dutch relations with China date back to the sixteenth century when Dirck Gerritszoon Pomp from Enkhuizen was a crew member of a Portuguese vessel which called at Chinese and other Far Eastern ports. Pomp's travels to China were recorded by Lucas Janszoon Waghenaer in his Thresoor der Zeevaert (Treasure of Shipping) ${ }^{1}$ which attracted the attention of the Gentlemen XVII, the Board of the Dutch East Indies Company, who were eager to enter into direct trade with the Chinese as a logical extension of their trade route to the Indonesian archipelago.

In 1601 and 1603, representatives of the Dutch East Indies Company sailed with a fleet to the Chinese coast, but were able to attain only superficial trade relations. In 1655, the first Dutch mission left for Peking with the object of gaining permission to trade on a regular basis. The mission failed, as did subsequent attempts. Finally, in 1686, a Dutch delegation to Peking succeeded in negotiating a trading privilege: every five years Dutch vessels were to be allowed to call at a Chinese port!

Trade relations continued to gradually develop between the two countries, but it was not until 1863 that the first treaty of friendship was concluded between the Netherlands and China. In 1880 the Dutch legation in Peking was established. Thereafter relations between Holland and China were maintained

*Secretary, Netherlands Council for Trade Promotion.

${ }^{1}$ L. WAGHENAER, THRESOOR DER ZeEVAERT (1592, reprinted 1965). 
on a regular basis, even after the 1949 Revolution, for the Netherlands recognized the regime of the People's Republic of China in 1950.

Nevertheless, the first two decades of the People's Republic did not manifest any great development in trade relations between the two countries. Following the Revolution, Chinese trade was conducted mainly with socialist countries, in particular with the U.S.S.R. Ideological considerations were, of course, one factor; another was China's entry into the Korean War, which resulted in strict controls being imposed by the Western countries on trade with China. These controls originated with the International Coordinating Committee on Strategic Trade with Communist Countries (COCOM), a committee formed by Western powers and Japan, which laid down trade policies and restricted those items which could be traded between the West and countries belonging to the Council for Mutual Economic Assistance (COMECON). ${ }^{2}$ In December, 1952, when China entered into the Korean War, COCOM formed the China Coordinating Committee (CHINCOM), to establish special controls on trade with the People's Republic and North Korea. The restrictive controls (primarily on strategic goods) were much more severe than those applied to trade with the East European bloc. The CHINCOM list contains over two hundred more embargoed items than are included in the COCOM list.

The failure of the Great Leap Forward and the ensuing depression, exacerbated by successive crop failures for several years, combined with the bitter Sino-Soviet dispute to cause a sharp decline in the total volume of Chinese trade in the early nineteen sixties. A slight recovery was made prior to 1966 , but the so-called Cultural Revolution from 1966 to 1968 caused another drop. At the same time, relations between the Netherlands and the People's Republic were independently suffering other strains. Throughout the nineteen sixties, Holland abstained from voting on the question of China's admittance into the United Nations. More dramatically, the so-called "welding technicians affair" in 1966 seriously disrupted Sino-Dutch relations, ${ }^{3}$ and China later accused the Dutch of playing an active part in the 1969 defection to the United States of Liao Ho-shu, the Charge d'Affaires ad interim in The Hague.

President Nixon's spectacular steps to resume cordial relations between the United States and China, which resulted in the entry of the People's Republic into the United Nations, signified a new era in Sino-Dutch relations. Diplomatic ties were increased to the ambassadorial level and various economic missions were exchanged. Commercial activity culminated in a Netherlands

${ }^{2}$ COMECON was formed on January 25,1949 , by the Soviet Bloc of Eastern Europe in response to the American-financed Marshall Plan. Its purpose was to provide communist funds for rebuilding Eastern Europe while aiding Soviet propaganda. Member nations include the U.S.S.R., Albania, Bulgaria, Czechoslovakia, East Germany, Hungary, Poland, and Rumania.

3 In 1966, a group of Chinese welding technicians attended a symposium in the Netherlands. One of them fell out of, or jumped from, the window of a rented residence in The Hague, where the group had been accommodated. He was badly injured and was taken to a hospital. From there, he was abducted by embassy personnel to the Chinese legation, where he died two days later. The Dutch police wanted to question his fellow countrymen, but were refused. The technicians remained confined in the embassy's compound, while in Peking the Dutch Charge d'Affaires was held as a "hostage." At the end of the year, the welding technicians were allowed to be questioned briefly by the Dutch authorities and subsequently repatriated. At the same time, the Dutch Charge d'Affaires returned to Holland. 
Industrial-Technological Exhibition and Symposium in Peking, and a Chinese Trade Exhibition in Amsterdam in the final months of 1973.

\section{Trade With Ghina}

\section{A. General Organization of Chinese Trade}

China's trade policy has been designed to achieve two goals: (1) to overcome the backwardness and the unequal trade relations which antedated the founding of the People's Republic in 1949; and (2) to attain a planned and systematic trade, in accordance with the demands of socialist doctrine and based on the principle of self-reliance. The trade policies adopted to achieve these ends have included planned trade, protectionism, the principles of equality and reciprocity, and the integration of politics and economics.

China's trade is all conducted by the state, based on plans formulated by the state. There are plans for each quarter of the year, annual plans, and longrange plans. The Ministry of Foreign Trade decides on target figures with the sectors concerned. These targets are indicated to the national trading corporations which must implement them. Each trading corporation specializes in a certain line of commodities. ${ }^{4}$ Each has its head office in Peking, but maintains branches in the most important industrial centers in China.

\section{B. Demand for Western Goods}

The potential appetite of the Chinese for Western goods is enormous. In the nineteen sixties China imported machinery, industrial goods (iron, steel, copper, rubber, cotton, and chemicals), fertilizers, and wheat. Before the SinoSoviet rift, China's desire to achieve industrialization as quickly as possible led to the importation of considerable machinery and equipment from the U.S.S.R., including over two hundred complete plants. In the past decade, however, China has turned to the West and to Japan to buy capital goods. The increasing significance of noncommunist nations as trading partners with the Chinese is apparent from Table I while the relative importance of certain kinds of commodities as imports is illustrated in Table II.

4 The trading corporations include: the China National Cereals, Oils, and Foodstuffs Import and Export Corporation; the China National Native Produce and Animal By-Products Import and Export Corporation (which handles foreign trade in tea, coffee, cocoa, spices, food products, animal products, feedstuffs, forest products, live animals, medicines, and so on); the China National Textiles Import and Export Corporation; the China National Light Industrial Products Import and Export Corporation (which controls foreign trade in such widely diversified areas as paper products, musical instruments, sporting goods, toys, building materials, electrical appliances, yarns, leather products, pottery and porcelain, human hair, pearls, precious stones and jewelry, ivory and jade carvings, lacquer ware, bamboo and rattan furniture and basketry, and so on); the China National Chemicals Import and Export Corporation; the China National Machinery Import and Export Corporation; the China National Technical Import Corporation; the China National Metals and Minerals Import and Export Corporation; the China National Foreign Trade Transportation Corporation; the China National Chartering Corporation (which charters vessels and books shipping space for China's import and export trade); and the Guozi Shudian (which handles the exporting of printed matter in Chinese and other languages). 
SinO-DuTCh TRADE

TABLE I

Major Trading Partners of China ${ }^{5}$

\begin{tabular}{|l|r|r|r||r|r|r|}
\hline \multicolumn{2}{|c|}{ (In \$ millions) } & \multicolumn{3}{|c|}{1971} & \multicolumn{3}{|c|}{1970} \\
\cline { 2 - 7 } & Exports & Imports & Total & Exports & Imports & Total \\
\hline East Asia \& Pacific & 989 & 687 & 1676 & 880 & 805 & 1685 \\
Japan & 323 & 579 & 902 & 254 & 569 & 823 \\
Hong Kong & 424 & 3 & 427 & 354 & 5 & 359 \\
Singapore & 113 & 15 & 128 & 107 & 23 & 130 \\
Australia & 41 & 27 & 68 & 36 & 129 & 165 \\
Malaysia & 50 & 18 & 68 & 58 & 22 & 80 \\
\hline East Bloc & 589 & 458 & 1047 & 491 & 353 & 844 \\
U.S.S.R. & 75 & 79 & 154 & 25 & 20 & 45 \\
Cuba & 70 & 65 & 135 & 75 & 70 & 145 \\
Rumania & 65 & 65 & 130 & 58 & 50 & 108 \\
North Korea & 65 & 65 & 130 & 65 & 65 & 130 \\
North Vietnam & 115 & 14 & 129 & 75 & 15 & 90 \\
Albania & 95 & 30 & 125 & 90 & 25 & 115 \\
\hline Western Europe & 381 & 560 & 941 & 357 & 665 & 1022 \\
West Germany & 95 & 139 & 234 & 84 & 167 & 251 \\
France & 71 & 113 & 184 & 70 & 81 & 151 \\
U.K. & 77 & 69 & 146 & 81 & 107 & 188 \\
Italy & 64 & 59 & 123 & 63 & 57 & 120 \\
Netherlands & 36 & 18 & 54 & 27 & 22 & 49 \\
\hline Africa & 192 & 140 & 332 & 125 & 70 & 195 \\
Tanzania & 87 & 12 & 99 & 37 & 8 & 45 \\
Sudan & 21 & 30 & 51 & 12 & 17 & 29 \\
Zambia & 5 & 45 & 50 & 1 & 14 & 15 \\
Morocco & 12 & 18 & 30 & 11 & 7 & 18 \\
\hline Near East \& South Asia & 179 & 133 & 312 & 180 & 130 & 310 \\
Pakistan & 37 & 29 & 66 & 28 & 39 & 67 \\
Sri Langka & 27 & 30 & 58 & 49 & 42 & 91 \\
Egypt & 19 & 22 & 41 & 15 & 18 & 33 \\
Kuwait & 21 & 3 & 24 & 20 & 2 & 22 \\
\hline Americas & 34 & 269 & 303 & 30 & 160 & 190 \\
Canada & 23 & 202 & 225 & 18 & 136 & 154 \\
Peru & 1 & 23 & 24 & & & \\
\hline
\end{tabular}

This buying pattern-as to both the source and nature of imports-is expected to continue throughout the nineteen seventies. The Chinese shopping list during this decade will include power plants, steel mills, fertilizer factories, industrial chemicals, advanced technical systems, sophisticated installations, and other goods that will speed up its program of industrialization, such as complete plants for making synthetic fibers. Most likely China will continue to buy wheat and fertilizer, while also rapidly expanding its oil (including offshore drilling) and petrochemical industries. However, there will be little or no

${ }^{5}$ Based on figures supplied by the U.S. Consulate General in Hong Kong. 
foreign exchange available for the purchase of consumer goods abroad. A slogan such as " 800 million pieces of soap-what a market!" belongs to the world of fairy tales.

\section{The Chinese Export Surplus}

While the importation of considerable amounts of capital goods is definitely a reality, inspection of Tables II and III reveals one important constraint: the Chinese always attempt to achieve an export surplus-though this was not accomplished in 1971-in order to build up currency reserves.

TABLE II

Estimates of Main Commodities Traded ${ }^{6}$

\begin{tabular}{|l|c|c|}
\hline (In \$ millions) & 1971 & 1970 \\
\hline Chinese Imports & & \\
Machinery and equipment & 495 & 395 \\
Iron and steel & 450 & 390 \\
Wheat & 204 & 275 \\
Fertilizer & 180 & 190 \\
Nonferrous metals & 155 & 170 \\
Chemicals & 130 & 140 \\
Rubber & 58 & 85 \\
\hline Chinese Exports & & \\
Foodstuffs & 800 & 655 \\
Raw materials, fuels, and edible oils & - & 435 \\
Textiles & 350 & 335 \\
Clothing & 200 & 155 \\
\hline
\end{tabular}

TABLE III

Estimated Ghinese Trade ${ }^{7}$

\begin{tabular}{|c|c|c|c|c|c|c|c|c|}
\hline \multirow{2}{*}{$\frac{(\text { In } \$}{\text { millions) }}$} & \multicolumn{3}{|c|}{$\begin{array}{l}\text { Chinese Exports to } \\
\text { East Noncommunist Total } \\
\text { Bloc Countries }\end{array}$} & \multicolumn{3}{|c|}{$\begin{array}{l}\text { Chinese Imports from } \\
\text { East Noncommunist Total } \\
\text { Bloc Countries }\end{array}$} & \multirow{2}{*}{$\begin{array}{c}\begin{array}{c}\text { Total } \\
\text { Volume }\end{array} \\
4470\end{array}$} & \multirow{2}{*}{$\begin{array}{c}\text { Export } \\
\text { Surplus } \\
170\end{array}$} \\
\hline & 550 & 1770 & 2320 & 400 & 1750 & 2150 & & \\
\hline 1970 & 515 & 1545 & 2060 & 325 & 1840 & 2165 & 4225 & 105 \\
\hline 1969 & 485 & 1535 & 2020 & 300 & 1535 & 1835 & 3855 & 185 \\
\hline 1968 & 460 & 1430 & 1890 & 340 & 1480 & 1820 & 3710 & 70 \\
\hline 1965 & 645 & 1310 & 1955 & 480 & 1260 & 1740 & 3695 & 215 \\
\hline 1962 & 920 & 605 & 1525 & 490 & 660 & 1150 & 2675 & 375 \\
\hline 1959 & 1595 & 610 & 2205 & 1365 & 695 & 2060 & 4265 & 145 \\
\hline 1956 & 1045 & 590 & 1635 & 1010 & 475 & 1485 & 3120 & 150 \\
\hline
\end{tabular}

Recent Sino-Dutch trade illustrates both Chinese demand for capital goods and the policy of the People's Republic regarding export surpluses. Table IV shows that Dutch imports exceeded Dutch exports to China in only 1968 among recent years. Table V reveals that Dutch exports to China over the past five 
years have primarily been shipments of fertilizer, which have been delivered by Nitrex (a consortium of producers in the Netherlands, Belgium, West Germany, France, Italy, Austria, and Norway) from factories in Holland. The first months of 1973 showed some improvement in the composition of Holland's export parcel, with the increases in the export of iron, steel, and machinery particularly noticeable. Against this limited diversification of exports, Table VI shows a broad and steady flow of Chinese goods to the Netherlands.

TABLE IV

SINO-DUTCH TRADE ${ }^{8}$

\begin{tabular}{|c|c|c|}
\hline $\begin{array}{c}\text { Dutch Exports } \\
\text { to China }\end{array}$ & $\begin{array}{c}\text { Dutch Imports } \\
\text { from China }\end{array}$ \\
\hline f $28,562,000$ & Jan.-Apr., 1973 & f $58,297,000$ \\
f $32,595,000$ & 1972 & f $145,425,000$ \\
f $61,310,000$ & 1971 & f $122,239,000$ \\
f $79,316,000$ & 1970 & f $96,722,000$ \\
f $83,270,000$ & 1969 & f $100,893,000$ \\
f $104,520,000$ & 1968 & f $98,338,000$ \\
f $44,340,000$ & 1967 & f $109,378,000$ \\
f $58,447,000$ & 1966 & f $92,020,000$ \\
f $68,617,000$ & 1965 & f $72,234,000$ \\
f $21,480,000$ & 1964 & f $57,031,000$ \\
f $46,668,000$ & 1963 & f $50,444,000$ \\
f $12,881,000$ & 1962 & f $55,602,000$ \\
f $15,049,000$ & 1961 & f $81,146,000$ \\
f $26,137,000$ & 1960 & f $65,065,000$ \\
f $42,377,000$ & 1959 & f $43,395,000$ \\
f $45,221,000$ & 1958 & f \\
f $20,979,000$ & 1957 &
\end{tabular}

TABLE V

Dutch Exports to ChinA ${ }^{9}$

\begin{tabular}{|l|c|r|r|r|r|r|}
\hline \multicolumn{1}{|c|}{ Product } & $\begin{array}{c}\text { Jan.-Apr. } \\
1973\end{array}$ & 1972 & 1971 & 1970 & 1969 & 1968 \\
\hline Urea & & 14.6 & 32.0 & 43.2 & 50.0 & 42.8 \\
Sulphate of Ammonia & & 2.5 & 5.2 & 15.6 & 15.7 & 26.1 \\
Nitro-chalk & & & & & 8.6 & 14.3 \\
Pharmaceuticals & 1.6 & 3.5 & 2.2 & 2.5 & 0.6 & 1.4 \\
Other chemical products & 4.5 & 3.0 & 3.0 & 1.0 & 3.6 & 9.2 \\
Nickel & 1.8 & 1.4 & 12.9 & 8.2 & 1.0 & 6.8 \\
Copper & & & & 0.7 & 0.1 & 0.4 \\
Ferrovanadium & 11.3 & 2.4 & & & & \\
Iron and steel & & 0.4 & & 1.1 & & \\
Rails & 4.2 & 1.4 & 0.8 & 3.0 & & 0.6 \\
Machinery & 1.2 & & & & & \\
Synthetic yarns & 1.5 & & & & & \\
Vegetable oils & & &
\end{tabular}

${ }^{8}$ Statistical figures in Dutch guilders (f) are based on statistics supplied by the Netherlands Central Bureau of Statistics.

${ }^{9}$ Id. The figures are expressed in $\mathrm{f}$ millions. 
TABLE VI

DUTCH IMPORTS FROM CHINA ${ }^{10}$

\begin{tabular}{|l|c|r|r|r|r|r|}
\hline \multicolumn{1}{|c|}{ Product } & $\begin{array}{c}\text { Jan.-Apr. } \\
1973\end{array}$ & 1972 & 1971 & 1970 & 1969 & 1968 \\
\hline Meat & 2.9 & 5.1 & 3.9 & 3.8 & 3.2 & 3.2 \\
Eggs & 0.9 & 0.4 & 1.3 & 1.5 & 2.0 & \\
Preserved fish & 1.5 & 3.2 & 2.6 & 2.4 & 1.7 & 1.3 \\
Rice & 0.9 & 1.8 & 0.6 & & 1.3 & 3.3 \\
Nuts & 0.7 & 0.5 & & & 0.9 & \\
Preserved fruit & 0.9 & 1.8 & 2.1 & 1.6 & 1.3 & 1.2 \\
Roots and tubes & 3.5 & 20.1 & & & & \\
Preserved vegetables & 3.1 & 6.8 & & & & \\
Tea & 0.9 & 2.5 & 1.7 & 1.1 & 0.8 & 1.4 \\
Tobacco & 0.4 & 1.1 & 0.9 & 0.7 & & \\
Sugar & 0.3 & 0.7 & 0.5 & & & \\
Spices & 0.2 & 0.9 & & & & \\
Oil seeds & 2.7 & 5.2 & 4.1 & 3.7 & 7.2 & 14.4 \\
Wool & 2.1 & 5.4 & 6.5 & 5.4 & 6.5 & 5.7 \\
Crude minerals & 2.1 & 5.6 & 2.6 & 3.9 & 2.0 & 1.5 \\
Crude animal materials & 7.4 & 20.2 & 20.5 & 22.7 & 19.2 & 13.1 \\
Oils and fats & 0.9 & 0.8 & 1.2 & 0.6 & 0.8 & 1.2 \\
Chemical products & 2.1 & 7.0 & 3.5 & 6.7 & 4.3 & 3.5 \\
Synthetic dyestuffs & 0.4 & & 0.2 & 0.3 & 0.3 & 1.1 \\
Essential oils & 0.4 & 1.2 & 1.4 & 1.3 & 1.3 & 1.9 \\
Textiles and clothing & 9.5 & 21.8 & 8.9 & 5.8 & 14.5 & 8.5 \\
Tin & 5.3 & 14.2 & 17.3 & 9.2 & 6.0 & 8.7 \\
Footwear & & 1.6 & 1.1 & 1.1 & 1.5 & 1.7 \\
Toys & 1.0 & 2.8 & 2.7 & 2.9 & 2.8 & 2.5 \\
Manufactured articles & 1.7 & 3.9 & 2.3 & 2.8 & 3.3 & 3.1 \\
\hline
\end{tabular}

Upon various occasions the Dutch have called the attention of the Chinese authorities to the unbalanced Sino-Dutch trade. The last time it was brought forward was in Peking in December, 1971, during the visit of a Netherlands economic mission. Both Mr. Li Hsien-nien (one of the Vice-Premiers) and Mr. Li Chiang (at the time Vice-Minister, now Minister, of Foreign Trade) assured the mission that China would like to increase trade between the two countries and to redress the balance which was too much in favor of the People's Republic. Henceforth, guilders would not be converted into foreign exchange, but would be used for purchases in the Netherlands.

It appears that the Chinese are living up to their promise, as recently Dutch enterprises received large orders for suction dredges, fertilizer plants, and cranes. In addition, it is hoped that the recent Netherlands IndustrialTechnological Exhibition and Symposium held in Peking will provide a source for increased Sino-Dutch trade. When prodded, the Chinese are thus willing to redress a trade imbalance which can result from the policy of the People's Republic regarding currency reserves.

${ }^{10} I d$. 


\section{Negotiating Chinese Trade Agreements}

\section{A. Commencing Trade Negotiations}

Foreign businessmen seeking to trade with the People's Republic should make their initial approach to the head office of the corporation concerned. The correspondence may be referred to one of the branches of the corporation, since trading of particular commodities is often entrusted to regional branches. The executives of these offices will handle the matter further; direct contact with final users of products is rare and only occurs after many years of a close trade relationship.

Replies to initial letters of inquiry vary in nature. Sometimes there is no reply at all, or there will be a long delay in receiving an answer. Alternatively, the reply may include a request for further information or the statement that there is no requirement for the merchandise offered at the present time. This apparently cumbersome procedure should not discourage foreign newcomers, and when they are convinced that their products do fill a need, they should see to it that their overtures are properly followed up by sending additional information, especially current catalogs, brochures, and samples.

Once the Chinese have shown interest in a product, further negotiations will prove much easier. Nearly half of China's foreign trade is transacted at the semiannual Canton Trade Fair, which runs from the 15th of April until the 15th of May, and from the 15th of October until the 15th of November. All the Chinese corporations are represented at the Fair, where both export and import trade are transacted. Access to the Fair is by invitation, which is usually obtainable from a trade corporation. ${ }^{11}$ The Fair itself involves exhibition buildings with an area of some 50,000 square meters. More than 30,000 items are on view, although these are not all for sale. Visitors to the Fair should not be in a hurry. They should plan to stay for at least a week, as negotiations may proceed slowly. When unusually large transactions-such as the purchase of a complete plant-are involved, negotiations take place in Peking, and the foreigner will be so informed.

\section{B. Contracts, Financing, and Payments}

Each of the Chinese trading corporations has its own contract forms, though the terms and conditions contained in these forms are invariably the same. Buyers of Chinese goods are usually required to obtain an irrevocable line of credit through the Bank of China in the People's Republic. Payment can be made in a Western currency. Dutch traders, for example, can settle in Dutch guilders. In recent years an increasing number of contracts have been negotiated in Ren Min Bi, "the people's money." However, since the RMB is not traded on exchange markets abroad, it is sold by the Bank of China to foreign traders only to settle their accounts with the Chinese trading corporations.

\footnotetext{
${ }^{11}$ The necessary visa may be acquired upon production of the invitation.
} 
Sellers to the People's Republic of China cannot obtain a confirmed line of credit since China does not follow the practice of having its credits confirmed by foreign banks. In fact, this is not necessary as the Bank of China has an excellent reputation among foreign traders for always fully honoring its obligations. As a matter of policy, the People's Republic maintains no long-term external debt. Some years ago even the debt to the Soviet Union was repaid in full.

\section{Methods of Settling Disputes}

In the various contracts of the corporations, the conditions are stipulated under which disputes may be settled. The Foreign Trade Arbitration Commission was established by the China Council for the Promotion of International Trade. It should be noted, however, that generally arbitration is discouraged by the Chinese. Only reluctantly will they resort to this way of settling, as it is regarded as evidence of bad faith. They much prefer settling by means of "friendly negotiations." Marine disputes, such as collisions, damage by vessels to port structures, or disputes over freight and agency services, can be brought before the Maritime Arbitration Commission.

\section{Shipping}

The China National Chartering Corporation handles shipping of both export and import goods. It charters vessels, books space for cargo, and acts as the agent in China for foreign shipping companies. The Chinese merchant navy is not large, but continually growing. China builds its own merchant vessels and regularly buys ships. The China National Foreign Trade Transportation Corporation arranges customs clearance and delivery of import and export goods by sea, land, or air. ${ }^{12}$

Until recently, certain Dutch shipping companies maintained regular services from Western Europe to various Chinese ports and vice versa. Now only vessels of Scan Dutch (a combination of Dutch and Scandinavian shipping companies) call at Shanghai. Royal Interocean Lines, a Dutch shipping company with only "cross trade services" (thus not calling at Dutch ports), has a regular service from China to African ports.

\section{E. Copyright, Trademarks, and Patents}

The People's Republic of China is not a member of the Bern Convention. As far as can be ascertained, no bilateral copyright agreement has been concluded between China and another country. In the early nineteen sixties, regulations were established in China permitting foreign enterprises to register trademarks in the People's Republic. The main requirements are that the trademark must first be registered in the home country and that there be a

\footnotetext{
${ }^{12}$ China prefers to buy f.o.b., and usually arranges its own insurance. Generally, c.i.f. is quoted for exports.
} 
reciprocal agreement between China and the owner's country. ${ }^{13}$

For registration of trademarks, the China Council for the Promotion of International Trade should be approached. Trademarks of medical products will only be registered if the Chinese health authorities have approved production in China.

The People's Republic does not possess a law on patents, which are considered the property of the state. A few foreign patents have been purchased from foreign sellers, but generally in connection with purchases of equipment or complete plants.

\section{ConCLUSION}

Trade with China is no simple matter. Success demands careful preparation, a convincing presentation at the Canton Fair or in Peking, and continuing perseverance. The Chinese are good businessmen, often hard and difficult in their negotiations. The Dutch experience, however, has been that contracts, once signed by the Chinese, are fully honored. The potential market for Western goods, as well as the extent of Chinese goods now available for export, make mastery of Chinese trade procedures well worth the effort for Western traders.

13 There is no agreement of any kind between China and the Netherlands. Since January 1,1973 , it has not been possible to conclude a trade agreement between the two countries because of Holland's membership in the European Economic Community. Any future trade agreement affecting the Netherlands would have to be concluded by the Community and China. 